The leaders in Michigan organization well understand their work has only begun; that physicians must be persuaded to work in their local branches, and those already therein encouraged to work out their own development, that of their branch, and the state society. The officers of the branches have this work primarily in charge. If they fail it is for the coun. cilor, by such means as seem wisest in each case, to awaken interest and stimulate effort. In fact, one great problem before the councilor is to find the best method of securing and keeping highest activity of the branches.

Should the councilor fail, his vice-president steps in to awaken him to duty. If he too fails, the president exercises his natural prerogative and stirs each to the desired activity. In Michigan it is expected that the president shall personally visit as many of the branches as possible, make a speech, read a paper, or hold a clinic, and in general use his office to increase the activity of the branches. Our late president set the pace for his successors in this direction.

Experience taught the councilor, when striving to organize or vivify a branch, that success followed a diversion from local quarrels and disputes to broader and larger questions thecting state or national interests. Fired with a larger thought, personal interests quietly dropped into their natural discionships. By such a method the writer has often seen a band iscordant group transformed, within an hour, into a smiling that of co-workers, ready to do and dare for the larger idea, that which its success demanded. In fact, the largest returns ganizorganization spring directly from this law-as the orcomers go out of themselves to help others their true selves profesto view--selves that make for all that is best in the ession, in manhood and citizenship.

The council's report showed that last September it started had ing succeeded beyond expectations, in áwakening and continupromterest among the branches, and its future looks very ing romising. The same report showed that experience was teachfrom the council how to secure increasingly large returns culties funds at its disposal, and how to adjust the diffgood. between individuals or branches for the common

Intelligent work, persistent and helpful to every physician Michigate, is the secret of such success as has obtained in re-elected To this end most of the officers of last year were act. The and the outcome demonstrates the wisdom of the selection fundamental platform of modern organization is the serve, not of officers for their known fitness and ability, to The not as figureheads or little gods.

gan, power of seventeen hundred united physicians in Michihas indicated ared with that of five hundred discordant ones, (1) It itself in many ways:

beretofore has given a self-confidence to the Michigan profession profession unfelt in its ability to help its members, the outside and secured the people. (2) It has spoken to the legislature because the a more respectful answer, because it had votes, and (3) As the chances were greater, that it expressed larger truth. meeting, six hundred members gathered in Detroit at its late trusting, the laity saw a vast concourse of physicians clearly evidently each other. It reasoned that if these learned men so as rulers trust each other, we may trust them, so the people with modern the land had a lesson that the new profession, Which "he that is organization, is certain to develop a profession in he that is greatest is servant of all."

$$
\text { Chairman Leartus Connor, A.B., M.D., }
$$

Touncil Michigan State Medical Society.

\section{The Demise of the "Philadelphia Medical Journal."}

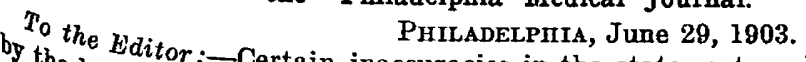

in the late editor-in-chin inaccuracies in the statement made in your issue editor-in-chief of the Philadelphia Aledical Journal, the profession for June 20, seem to need correction in order that adorns this may be better able to point the moral which "Tro and tale. I refer particularly to the words:

reached a crisis alf years ago the Philadelphia Medical Journal a crisis in its afrairs which led to a change in editorial management. . There were many prominent medical men in Philadelphia and elsewhere who were interested in keeping the journal alive; and in spite of the fact that its short career up to that time had been marked by threatening disaster (due Iargely to the opposing aims and temperaments of men who commanded its various departments), a determined effort was made to rehabilitate the journal and give it a new lease of life. At the same time, however, the command of its stock was allowed to remain in the hands of a few (and a very few) laymen."

It is true that the difficulty two and a half years ago was that of "opposing aims and temperaments," but these were the old division betwixt commercialism vs. ethics. It was this that culminated in the displacement of the editor by the commercial interests, in order (as was stated at the time), to install some one who might either be hoodwinked by them or who would be pliable to the demands of commercialism. The "impending disaster" was brought into existence solely as a reason to give for deposing an editor who refused to be subservient. These facts were made known to the late incumbent personally before he assumed the position of editor-in-chief, following my dismissal and the abrogation of the office of editor, and were also made known to the profession in general by a "protest" presented at the annual stockholders' meeting of the Philadelphia Medical Publishing Company, and thereafter sent to practically every physician in the United States and Canada. It will be remembered that this protest was directed chiefly against the condition outlined in the last sentence of the quotation from the communication of the late editor-in-chief--the placing of the absolute control of a medical journal in the hands of practically one stockholder, a layman.

Not a word or sign of dissent to the statements contained in that protest has ever been made, and this letter by the recent editor-in-chief is an unexpected confirmation of their absolute truth, and reveals the rapid degeneration of the journal during the two and one-half years following. The disastrous conditions which have made the Philadelphia Hedical Journal "practically dead in the city of its birth" have developed within the past three years. They could, however, never have prevailed had not the indifferent and apparently consenting attitude of a few physicians confirmed the commercial element in a belief that "professional ethics" existed only in the mind of the deposed editor, and that the profession would believe anything they pleased to say, if it was only said often enough and loud enough. Indifferent authors would help them by contributing their articles, indifferent physicians would send in subscriptions, and a mint of money could be made out of them and out of advertisers with the aid of subservient professional helpers! When my incumbency as editor was terminated, the journal (according to report of its business manager) had close on 12,000 subscribers. That these were gained through confidence in the editorial conduct of that journal was shown by the fact that American sfedicine, which two and a half years ago took up the spirit and aims laid down by the Philadelphia Afedical Journal, had 12,000 subseribers in less than nine months from its inception. Having faith in the existence of professional sentiment and recognizing that, if it could build a journal like the Philadelphia Medical Journal was two and a half years ago, it could also maintain it, and desiring to avert the blight of commercialism from so fair a property, I made a proposition to the board of directors prior to the final act of my dismissal, offering to lease the journal from them for any period of years they should name, assuming entire editorial and business charge and guaranteeing them as rental an annual payment of 5 per cent. on the then capital stock of $\$ 60,000$. Under the conditions that then existed, with one journal in Philadelphia and with a different business management, this could have been done.

The communication of the late editor-in-chief is but a continuation of the story told in my "protest," and emphasizes the warning of the dangers of commercialism in medicine as much by what it leaves unsaid as by the degrading conditions it reveals. Those in the profession and those dependent on the profession may read their lessons, the one of the evils resulting 
from the unfaith of commercialism, the other that ethical senti. ment is growing, and that though commercial cunning may apparently prevail for a time, its portion will eventually be meted out to it.

George M. Gould.

\section{Indian Method of Treating Measles.}

OGDEN, Utar, June 28, 1903.

To the Editor:-Speaking of the Indian and his improvised Turkish bath, and the observations of MeClanahan and Judd, I beg to say that when I was connected with the Winnebago and Omaha agencies some years ago the Indians there improvised a Turkish bath exactly as described by Dr. Judd in The Journal of June 27. Dr. Judd queries whether the Indian would go into cold water after this hot bath if the water were available. That is exaetly what they all did at the Omaha reservation. I remember an epidemic of measles in which I had little to do other than look on, for they had a Medicine Man of their own and were impatient of any interference from me or any one. The disease was confined principally to the papooses under 10 or 12 years old. They did very little till the trouble was well established, then the patient was carried into an already prepared tepee of hides, usually buffalo skins, where it was rolled in a heary blanket and laid in a rudely-constructed eradle made of the limbs of trees. Rocks had already been heated and now water was poured over them. Prior to this, however, the Medicine Man was in evidence and I had been relegated. He first seraped the vertex of the caput with a horn or piece of glass, and when the spot was thin enough the shell of a small horn, usually that of a young buffalo, was placed thereon after the air had been exhausted, I do not remember how, something after the manner of a cupping glass. Then the Medicine Man, assisted by the gifted of the tribe, sought to exercise the evil spirit that had entered into the little victim. This was done by the beat ing of tom-toms and other added instruments, including the human voice, that made the sueceeding days and nights ones of horror. The flaps of the tepees were pinned down tightly to the ground, and after a little the odor inside, coming from a combination of steam, hides, heat and Indian, would stop a clock. The "hospital" tepee was always pitehed on the bank of a stream of water, and as these epidemics of measies always occurred in winter ( $I$ do not remember of one at any other season) the stream was therefore frozen over. While the heating was going on some were cutting a hole through the ice. At the proper time the now half-dead young Indian was brought out, his blanket removed, and be was plunged into the iey water, perspiration and all. In a few mimutes he would be returned to the tepee and the process repeated. The above will to many almost incredible, but it is true. Another incredible thing is that the little papooses thus treated sometimes recovered.

A. S. Condon, M.D.

\section{Protracted Anesthesia.}

Amesbury, Mass., June 28, 1903.

To the Editor:-The subject embraced in the above title is one that $I$ have not seen discussed in medical journals. I have no desire to act the part of the carping critic in considering modern methods of surgery; I am quite ready to acknowledge the wonderful progress made by the masters of the knife in the last forty years. To an old-time military surgeon the present results in treatment of wounds seem little less than a miracle. I have spent many hours removing maggots from suppurating stumps after operations, so that the dry antiseptic dressing seems like a page from a fairy tale.

The old-time surgeon had certain qualifications for which he should be given credit. He was a rapid operator. Prior to ether and chloroform the length of time required for an operation weighed heavily in the scale of results. Shock was rated in proportion to the Iength of suffering.

In the opinion of the writer the modern surgeon is losing sight of possible shock by too deliberate methods. In a large hospital a few days ago I saw a patient wheeled into the operating room fully anesthetized. The surgeons were preparing their hands and donning their robes with no attempt at haste.
The theory was that the patient was not suffering and consequently they could take their time.

Now ether is either an advantage medically considered or a disadvantage. If it is of real decided benefit to the patient then protracted anesthesia is all right. If it is not, then this laggardly waste of time is wrong, and we are not giving our patients the best possible chance.

The writer has been under the surgeon's knife five different times with an experience varying from a few minutes to five hours' anesthesia, and from a personal standpoint is confident that the strain on the nervous system, even under ether, is no insignifieant matter. Personally, I would not like to have patient of mine lose three minutes' time under ether waiting for a surgeon.

H. G. IESLIE, M.D.

\section{Reciprocity-A Suggestion.}

Selma, Ara., June 30, 1903.

To the Editor:-For some time I have noticed that you have been trying to perfect some system of reciprocity be tween the licensing boards of different states. The schere which I propose, if it could be carried out, might help those who have stood an examination in one state in getting license in another. Should a physician practicing in one state wish to move to another he might be given the choice of stand ing the examination of the state into which he moves or allowed to show his examination papers of the state in whict be had already practiced; if these papers conform to the standard of the state into which he moves at the time of the examination be to be given a license in this state.

A recent graduate might make a very fine showing before o.p board, but should he try an examination in another state sop five or six years later, though he knew considerably more thes a man fresh from college, he would not be able to make g good a percentage. This manner of getting a license in other state without standing the examination is defective. that it applies to only those who have slood a written examinus tion before an examining board.

H. D. Funviss.

\section{Queries and Minor Notes.}

Axosysous Communicamions will not be nóticed. Querles 10 this column mast be accompanted by the writer's name and addre but the request of the writer not to publish bis'name will be falt fully observed.

\section{PRESCRIBING WHISKEY}

Shreve, Ogio, Iune 26, 190\%

To the Rditor:-Is it lawful for a physician to prescribe whld for a patient, then dispense the whiskey, charging the patient retail price of the whiskey, but making no other charges, i. en
professional services?

ANs.-A physician who would do thls would be simply seller and should take out a government and local license.

\section{Book Notige.}

The Practical Application of THz Ronstam RaY8 in Thl PEUTICS AND DIAGNoSis. By William Allen Pusey, A.M., Professor of Dermatology in the University of Illinols; and nu W. Caldwell, B.S., Director of the Edward N. Gibbs X-Ray orial Laboratory of the Oniversfty and Bellevue Aospital Med College, New York. Cloth. Fp. 591. With 180 Illustrat. Nearly all Clinical. Price, \$4.50 net. Philadelphla:
Saunders \& Co. 1903.

This volume is practically two books, one being devoted $x$-rays as a diagnostic and the other as a therapeutic ag Part one is written by Director Caldwell of the Gibbs Laboratory of New York, a man thoroughly competent, thro 0 practical experience, to write on the subject assigned him. an introductory chapter is given a brief review of the perimental work which led up to the discovery of $x$-rays, follow a description of the apparatus used, one chaptar devoted to the Essentials of an $X$-ray Outfit, another to $X$ Tubes, one to Induction Coils, Interrupters and Their agement, one each to Static Machines and Their Manage to Fluoroseopy, to Photographic Materials and Their Mco lation, and sources from which the electric current mos? obtained.

The chapter on Radiography is a most important and able one. In it are given in detail practical snggestios 